\title{
Identification of the association between FABP4 gene polymorphisms and milk production traits in Sfakia sheep
}

\author{
Adel H. M. Ibrahim ${ }^{1}$, Nikolaos Tzanidakis ${ }^{2}$, Smaragda Sotiraki ${ }^{2}$, Huitong Zhou ${ }^{3}$, and \\ Jonathan G. H. Hickford ${ }^{3}$ \\ ${ }^{1}$ Department of Animal Breeding, Desert Research Center, 1 Matehaf AlMatariya St., \\ AlMatariya, Cairo 11753, Egypt \\ ${ }^{2}$ Veterinary Research Institute, Hellenic Agriculture Organization, Thermi, TK 57001, Thessaloniki, Greece \\ ${ }^{3}$ Gene-Marker Laboratory, Department of Agricultural Sciences, Lincoln University, \\ POB 84, Lincoln 7647, New Zealand
}

Correspondence: Adel H. M. Ibrahim (adelhosseiny2005@yahoo.com)

Received: 25 February 2019 - Accepted: 17 June 2019 - Published: 15 July 2019

\begin{abstract}
The aim of this study was to estimate the effect of variation in the fatty acid binding protein 4 gene (FABP4) on milk production traits in Greek Sfakia sheep. Polymerase chain reaction - single-stranded conformational polymorphism (PCR-SSCP) analysis was used to genotype a total of 374 Sfakia ewes for two regions of FABP4 located around exon 2-intron 2 (Region 1) and exon 3-intron 3 (Region 2). Each month, for a period of 6 months, milk samples were collected from the ewes to measure total milk yield, fat content, protein content, lactose content, non-fat solid content, $\mathrm{pH}$, and somatic cell count (SCC). A general linear model was used to test the association between the variation observed in FABP4 and milk production traits. Four gene variants $(A 1-A 4)$ were found in Region 1 and two variants $(C 1-C 2)$ were found in Region 2 . In the first region, the FABP4 genotype significantly affected $(P<0.05)$ non-fat solid levels, fat content, and SCC. The presence of the $A 2$ variant was significantly associated $(P<0.05)$ with decreased SCC, while the presence of $A 4$ was significantly associated with decreased milk yield $(P<0.01)$, increased non-fat solid content $(P<0.05)$, decreased fat content $(P<0.01)$, increased lactose content $(P<0.05)$, and increased $\mathrm{pH}(P<0.05)$. In the second region, $F A B P 4$ genotype had an effect $(P<0.05)$ on protein content and the presence of the $C 2$ variant was associated $(P<0.05)$ with increased protein content, decreased SCC, and lower $\mathrm{pH}$. The results suggest an association between variation in ovine FABP4 and milk production traits in Greek Sfakia sheep. Nevertheless, further analyses in independent sheep populations of increased size will strengthen these findings.
\end{abstract}

\section{Introduction}

Sheep rearing for meat and milk production is an important part of the economy in the rural regions of Greece, contributing around $18 \%$ to agricultural income and representing more than half of the country's animal production (Hadjigorgiou, 2014). The Sfakia breed is one of the most popular dual-purpose breeds of Greek sheep and its milk is used for consumption and for processing into cheese and yogurt. Sheep milk has advantages over cow milk because it contains higher levels of protein, lower levels of cholesterol, and large amounts of vitamins $\mathrm{A}$ and $\mathrm{E}$, which act as antioxidants (Khan et al., 2019). With sheep milk, producing $1 \mathrm{~kg}$ of cheese takes approximately $4 \mathrm{~kg}$ of milk, compared to 8 to $10 \mathrm{~kg}$ for cows (Zeola et al., 2015).

Increasing the productivity of milking sheep is very important if the purpose is to increase the income of Greek farmers. Accordingly, it is important to understand the genetic basis of milk production traits. One approach, which has gained in popularity, is to search for the genetic basis of the important traits and select superior breeding stock using markerassisted selection. The use of marker-assisted selection can 
speed up the identification of genetically superior animals by increasing the accuracy in which genetic merit can be ascertained, and by decreasing generation interval (Williams, 2005). To achieve this outcome, you first need to identify the major genes that affect any valued traits (Zhu and Zhao, 2007).

The various components of milk originate from blood plasma substrates and they are synthesized in the epithelial cells of the mammary gland (Kulig et al., 2013). Milk lipids are synthesized from fatty acids that bind to specific proteins called fatty acid binding proteins (FABPs). The FABPs are a small family of cytoplasmic proteins. They are thought to affect various cellular processes, in-particular lipid metabolism. They do this by transferring the fatty acids, heme, retinoids, and different vitamins across the cytoplasmic membrane to the sites of $\beta$-oxidation and triglyceride and phospholipid synthesis, and by modulating the concentration of the fatty acids in cells (Kulig et al., 2013).

To date, nine members of the FABP gene family (FABPI$F A B P 9)$ have been described. Fatty acid binding protein 4 (FABP4), also known as adipocyte FABP (A-FABP), is a protein found in abundance in the mammary gland, and also in mature adipocytes and adipose tissue (Hunt et al., 1986). The gene for FABP4 (FABP4) is expressed during lactation (Bionaz and Loor, 2008) and the main function of this protein is thought to be in lipid metabolism, where it binds both long-chain fatty acids and retinoic acid and delivers them to receptors in the nucleus of adipocytes (Spiegelman and Green, 1980).

Investigations of FABP4-deficient mice suggest that thermogenesis and whole-body energy expenditure are decreased after feeding on a high-fat diet, indicating the importance of FABP4 in the maintenance of normal lipid metabolism (Cao et al., 2008). Furthermore, FABP4 was found to increase thermogenesis by promoting the conversion of thyroid hormone from its inactive form (T4) to active form (T3) in brown adipocytes, the levels of FABP4 were found to increase in the bloodstream, and in both brown and white adipose tissues, in response to thermogenic stimuli (Shu et al., 2017). In this respect, it has been shown that the performance of lactating animals is not only limited by the intrinsic properties of mammary glands but also by competition from heat production including thermogenesis in brown adipose tissue (Król et al., 2011). Taken together, these suggest that the performance of lactating ewes could be affected by FABP4.

The FABP4 gene has been identified in sheep, cattle, chickens, and humans. Across these species it has a conserved structure with four exons being separated by three introns. Studies on whether variation in FABP4 affects milk production traits in sheep have not been undertaken but Yan et al. (2012) analyzed two regions of the gene (Region 1: exon 2-intron 2; and Region 2: exon 3-intron 3) using polymerase chain reaction - single-stranded conformational polymorphism (PCR-SSCP) and DNA sequencing. They detected five different SSCP patterns derived from three nu- cleotide substitutions and one deletion in Region 1 and four different SSCP patterns derived from four nucleotide substitutions in Region 2.

It is assumed that the lipid metabolism, thermogenesis, and whole-body energy expenditure affects most biological functions in the cells of various tissues and organs, including the mammary gland; therefore, FABP4 is considered to be a candidate gene for milk production traits in sheep. The objective of the present study was therefore to look for genetic variation in two separate regions of ovine FABP4 gene and, if found, test its association with milk production traits in Greek Sfakia ewes.

\section{Materials and methods}

\subsection{Animal sources and experimental design}

Twenty $(n=20)$ different flocks of the Sfakia breed, from the provinces of Rethymno and south Chania on Crete, were investigated. Ten flocks were representative of a semi-intensive production system and the other 10 were representative of the more traditional extensive production system. Within each flock, 18-20 ewes (in their second or third lactation) were randomly chosen for analysis. Eight to 10 ewes were randomly chosen from the early lambing period in autumn, when the multiparous ewes lamb, and 9 to 10 ewes were randomly chosen from the late lambing period in winter, when the primiparous ewes lamb.

\subsection{Phenotypic measurements and analytical methods}

All ewes were milked twice daily and the daily milk yield was measured using graduated measuring cylinders. Milk samples for analysis were collected once a month for a period of 6 months. These samples were analyzed at the State Milk Quality Laboratory (ELOGAK) in Rethymno. First, the samples were heated to $25^{\circ} \mathrm{C}$ and the $\mathrm{pH}$ measured. For samples with a $\mathrm{pH}$ above 6.0 , fat percentage, protein percentage, lactose percentage, and non-fat solid percentage were assessed by infrared analysis using a MilkoScan ${ }^{\mathrm{TM}}$ (FT, FOSS ${ }^{\circledR}$, Hillerød, Denmark) and by flow cell cytometry for somatic cell count (SCC) using the Fossomatic ${ }^{\mathrm{TM}}$ (FC, FOSS $^{\circledR}$ ). Fat, protein, lactose, and non-fat solid contents in the milk were expressed in grams per $100 \mathrm{~mL}$ and the logarithmic value of somatic cell count in milk was recorded.

\subsection{PCR-SSCP analysis and genotyping of FABP4}

Blood samples were collected from 374 Sfakia ewes onto FTA cards (Flinders Technology Associates); genomic DNA was purified for PCR analysis using a two-step procedure that is described by Zhou et al. (2006). Two pairs of specific primers (Table 1) were used to study the genetic variation in two regions of the FABP4 gene (Region 1 and Region 2) that are located on exon 2-intron 2 and exon 3-intron 3. 
Table 1. List of primer sequences used for PCR.

\begin{tabular}{lcll}
\hline Region amplified & Size (bp) & Primer sequence & Reference \\
\hline $\begin{array}{l}\text { Region 1 } \\
\text { (exon 2-intron 2) }\end{array}$ & 350 & F: CAGGAATTTGATGAAGTCACT & Yan et al. (2012) \\
\hline $\begin{array}{l}\text { Region 2 } \\
\text { (exon 3-intron 3) }\end{array}$ & 524 & F: GATGGGAAATCAACCACCA & Yan et al. (2012) \\
\hline
\end{tabular}

$\mathrm{F}=$ forward $\mathrm{R}=$ reverse.

The PCR reaction was carried out in a total reaction volume of $20 \mu \mathrm{L}$ containing the DNA on a $1.2 \mathrm{~mm}$ punch of FTA card, $0.25 \mu \mathrm{M}$ of each primer, $2.5 \mu \mathrm{L}$ of $10 \times$ PCR buffer, $1.5 \mathrm{mM}$ of $\mathrm{MgCl}_{2}, 150 \mu \mathrm{M}$ of each dNTP (Eppendorf, Hamburg, Germany), and $0.5 \mathrm{U}$ (one unit) of Taq DNA polymerase (Qiagen, Hilden, Germany). The thermal profile consisted of a 2 min denaturation at $94^{\circ} \mathrm{C}$ followed by $35 \mathrm{cy}-$ cles of $30 \mathrm{~s}$ at $94^{\circ} \mathrm{C}, 30 \mathrm{~s}$ at $60^{\circ} \mathrm{C}$, and $30 \mathrm{~s}$ at $72^{\circ} \mathrm{C}$, and with a final extension step of $5 \mathrm{~min}$ at $72^{\circ} \mathrm{C}$. The PCR products were subject to single stranded conformational polymorphism (SSCP) analysis in $14 \%$ polyacrylamide gels at $320 \mathrm{~V}$ and $12{ }^{\circ} \mathrm{C}$ for $18 \mathrm{~h}$ in $0.5 \times \mathrm{TBE}$ buffer, and the gels were silver-stained using the method of Byun et al. (2009).

\subsection{Sequencing and analysis of the sequence variation}

The amplicons from two sheep that produced each homozygous SSCP pattern for FABP4 were used as templates for Sanger sequencing of DNA at the Lincoln University DNA Sequencing Facility. For each heterozygous SSCP pattern, two sheep were sequenced using the method of Gong et al. (2011). Briefly, one of the unique bands of the heterozygous pattern was cut out of the gel, washed with $300 \mu \mathrm{L} 1 \times$ TE buffer, mashed up with a micropipette tip in $30 \mu \mathrm{L} 1 \times$ TE buffer and incubated for $50 \mathrm{~min}$ at $55^{\circ} \mathrm{C}$. This product was used as the DNA template for re-amplification using the PCR conditions described above. The re-amplified DNA was purified using a PCR purification kit (Thermo Fisher Scientific, Waltham, MA, USA) and then sequenced in both directions. DNA sequence analyses, including translation to amino acid sequence and sequence comparisons, were undertaken using DNAMAN software (version 7.212, Lynnon Corp., QC, Canada) and DNASTAR software (Madison, WI, USA).

\subsection{Statistical analyses}

Data were analyzed using the general linear model (GLM) procedure of SAS software (SAS, 2004) to estimate the effect of $F A B P 4$ genotype, lactation number, lambing period, and management system. Sheep with FABP4 genotypes with frequencies less than $4 \%$ were omitted from the statistical analysis to reduce the chances of obtaining false positive results during the multiple comparisons.

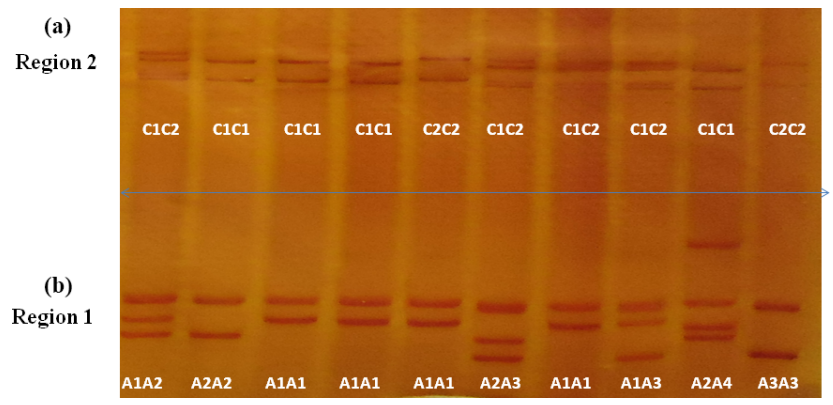

Figure 1. PCR-SSCP for exon 2-intron 2 (b) and exon 3-intron 3 (a) of the FABP4 gene in Sfakia ewes.

The mathematical model used can be written as follows:

$Y_{i j k l m}=\mu+G_{i}+B_{j}+C_{k}+\mathrm{FM}_{l}+e_{i j k l m}$,

where $Y_{i j k l m}$ is the observed trait value in the $i j k l m$ th animal, $\mu$ is the mean trait value for a given trait, $G_{i}$ is the fixed effect of the $i$ th $F A P B 4$ genotype ( $i=1$ to 5 for the first region and $i=1$ to 3 for the second region) or the fixed effect of the presence or absence of each detected FAPB 4 variant ( $i=0,1$ for each variant, in each region), $B_{j}$ is the effect of lactation number $(j=2,3), C_{k}$ is effect of lambing period $(k=1,2), \mathrm{FM}_{l}$ is the fixed effect of $l$ th farm $(1, \ldots 10)$ for each management system $(1,2)$, and $e_{i j k l m}$ is the random error.

The differences between mean trait values were verified by the Duncan test $(P \leq 0.05)$.

\section{Results}

\subsection{Identification of sequence variation in FABP4}

Four different SSCP banding patterns were observed for amplicons derived from the exon 2-intron 2 region of FABP4 in the Sfakia sheep, and 10 combinations of these banding patterns corresponded to 10 different genotypes (named: A1A1, A1A2, A1A3, A1A4, A2A2, A2A3, A2A4, A3A3, A3A4, and $A 4 A 4$; Fig. 1). These had frequencies of $17.1 \%, 31.6 \%$, $14.4 \%, 6.3 \%, 15.9 \%, 8.8 \%, 3.8 \%, 0.7 \%, 0.7 \%$, and $0.5 \%$, respectively. They were comprised of four unique variant sequences ( $A 1, A 2, A 3$, and $A 4$; Table 2 and Fig. 2) with frequencies of $43.3 \%, 38.0 \%, 12.8 \%$, and $5.9 \%$, respectively. 
Table 2. Sequence variation in the two regions of ovine $F A B P 4$.

\begin{tabular}{|c|c|c|c|c|c|}
\hline & \multirow[t]{2}{*}{ Position } & \multicolumn{4}{|c|}{ Nucleotide sequence } \\
\hline & & $A 1$ & $A 2$ & $A 3$ & $A 4$ \\
\hline \multirow[t]{6}{*}{ Region 1} & c. $246+34$ & $\mathrm{C}$ & - & $\mathrm{C}$ & $\mathrm{C}$ \\
\hline & c. $246+37$ & G & A & A & A \\
\hline & c. $246+46$ & $\mathrm{C}$ & $\mathrm{C}$ & $\mathrm{C}$ & $\mathrm{T}$ \\
\hline & c. $246+47$ & G & G & G & $\mathrm{G}$ \\
\hline & Position & \multicolumn{4}{|c|}{ Nucleotide sequence } \\
\hline & & \multicolumn{2}{|c|}{$C 1$} & \multicolumn{2}{|c|}{$C 2$} \\
\hline \multirow[t]{2}{*}{ Region 2} & c. $348+298$ & \multicolumn{2}{|c|}{$\mathrm{T}$} & \multicolumn{2}{|c|}{$\mathrm{C}$} \\
\hline & c. $348+356$ & \multicolumn{2}{|c|}{$\mathrm{T}$} & \multicolumn{2}{|c|}{$\mathrm{C}$} \\
\hline
\end{tabular}

The variant frequencies for the second region of $F A B P 4$ in the Sfakia sheep were $73.0 \%$ and $27.0 \%$ for variants that were named $\mathrm{Cl}$ and $\mathrm{C2}$, respectively. Three genotypes were observed: $\mathrm{ClCl}$ (frequency $53.0 \%), C 1 C 2(40.0 \%)$, and $C 2 C 2(7.0 \%)$ (Table 2 and Fig. 2).

\subsection{Effect of nongenetic factors on milk production traits}

The nongenetic factors (lactation number, lambing period, and farm-management system) significantly $(P<0.05, P<$ $0.01)$ affected all of the milk production traits for the Sfakia ewes.

\subsection{Effect of FABP4 genotype in the first region on milk traits}

Associations between the FABP4 genotypes in the first region and the milk production traits are summarized in Table 3. Associations $(P<0.05)$ were observed between FABP4 genotypes in the first region and non-fat milk solids, fat content, and SCC. Ewes with the AlA4 genotype had higher non-fat solid levels, lower fat content, and lower SCC, while ewes with the $A 2 A 3$ genotype had lower non-fat solid levels and higher fat content. Furthermore, a trend $(P=0.082)$ was observed for an association between the FABP4 genotype in the first region and milk yield. Ewes with the AlA4 genotype had lower milk yields, while the $A 2 A 3$ ewes had higher milk yields.

The results of testing the association between absence or presence of the FABP4 variants of the first region in ewe genotype and milk production traits are presented in Table 4. These results reveal that the presence of $A 2$ in the genotyped ewes was associated with decreased SCC $(P<0.05)$, while the presence of $A 4$ in the ewes was associated with decreased milk yield $(P<0.01)$, increased non-fat solid content $(P<0.05)$, decreased fat content $(P<0.01)$, increased lactose content $(P<0.05)$, and increased $\mathrm{pH}(P<0.05)$.

\subsection{Effect of FABP4 genotype in the second region on milk traits}

The results in Table 3 reveal that FABP4 genotype in the second region had an effect on protein content $(P<0.05)$. A comparison of the milk production traits for the $F A B P 4$ genotypes proved that the ewes with the $C 2 C 2$ genotype had the highest protein content, while the ewes with the $C 1 C 1$ genotype had the lowest protein content. As shown in Table 4, the presence of the $C 2$ variant in the ewe genotype was associated $(P<0.05)$ with an increase in protein content, and decreases in $\mathrm{pH}$, and SCC.

\section{Discussion}

This is the first report describing the effect of FABP4 variation on milk production traits in sheep. In the study, a PCRSSCP method proved to be a robust and reliable way to identify genetic markers associated with milk traits in Sfakia sheep. It unambiguously revealed 10 combinations of four PCR-SSCP patterns that were made up of four unique DNA sequences from the exon 2-intron 2 region of FABP4 and three combinations of two PCR-SSCP patterns representing two unique DNA sequences from a part of exon 3 and intron 3. On the basis of sequence comparison, the FABP4 variants $A 1, A 2, A 3$, and $A 4$ described here appeared to match variants $A l, B l, C l$, and $D l$, respectively, as described by Yan et al. (2012) and listed in GenBank with accession numbers JX290313-JX290316. It is evident from Tables 3 and 4 that there are significant associations for the variation observed in Region 1 of FAPB4 with milk yield, non-fat milk solid content, fat content, lactose content, $\mathrm{pH}$, and SCC. While the nucleotide substitutions that were found in this region are located in intron 2, and do not change the amino acid sequence, it is possible that these substitutions might still influence $F A B P 4$ expression. For example they might affect the splicing of mRNA or be linked to variation elsewhere in a regulatory region (e.g., a miRNA binding site or enhancer binding site), or the $5^{\prime}$-UTR or $3^{\prime}$-UTR regions (UTR is untranslated region), that subsequently affects expression of the amino acid sequence (Wessagowit et al., 2005; MartõÂnezPizarro et al., 2018).

Previous reports have demonstrated associations between genetic variation in FABP4 and carcass traits, meat quality traits, and fatty acid composition in adipocytes (Ardicli et al., 2017; Yan et al., 2018). Limited information is available regarding the effect of $F A B P 4$ on milk production traits in livestock. In Jersey cattle, Kulig et al. (2010) studied variation in two regions of the bovine FABP4 gene (from nucleotides 5433 to 6106 and from nucleotides 7417 to 7868 ), for the accession number AAFC01136716, and found no associations between the FABP4 polymorphism and daily milk yield, percentage fat content, or percentage protein content. For the same regions of FABP4 in Polish Holstein-Friesian cows, Kulig et al. (2013) revealed a significant effect for 


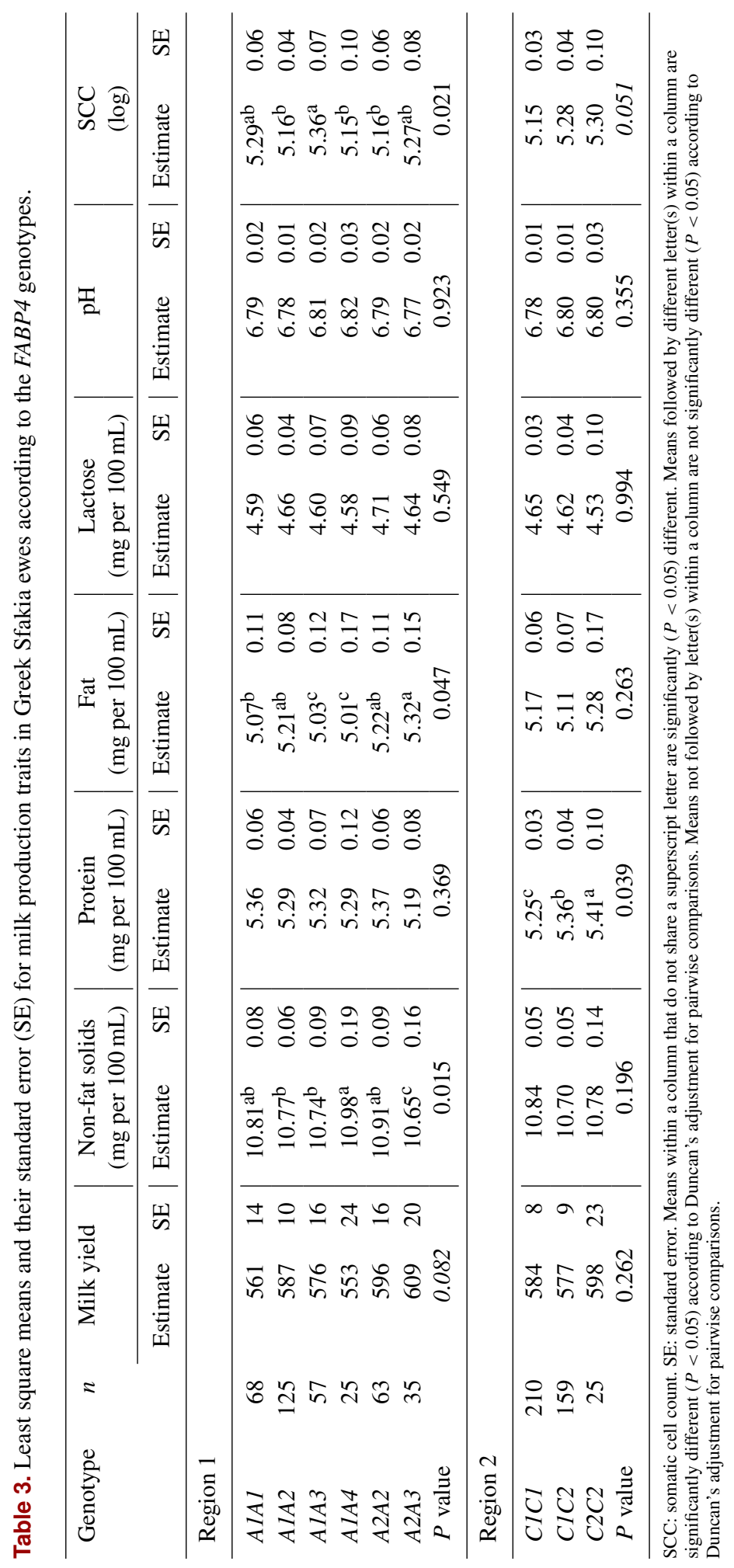




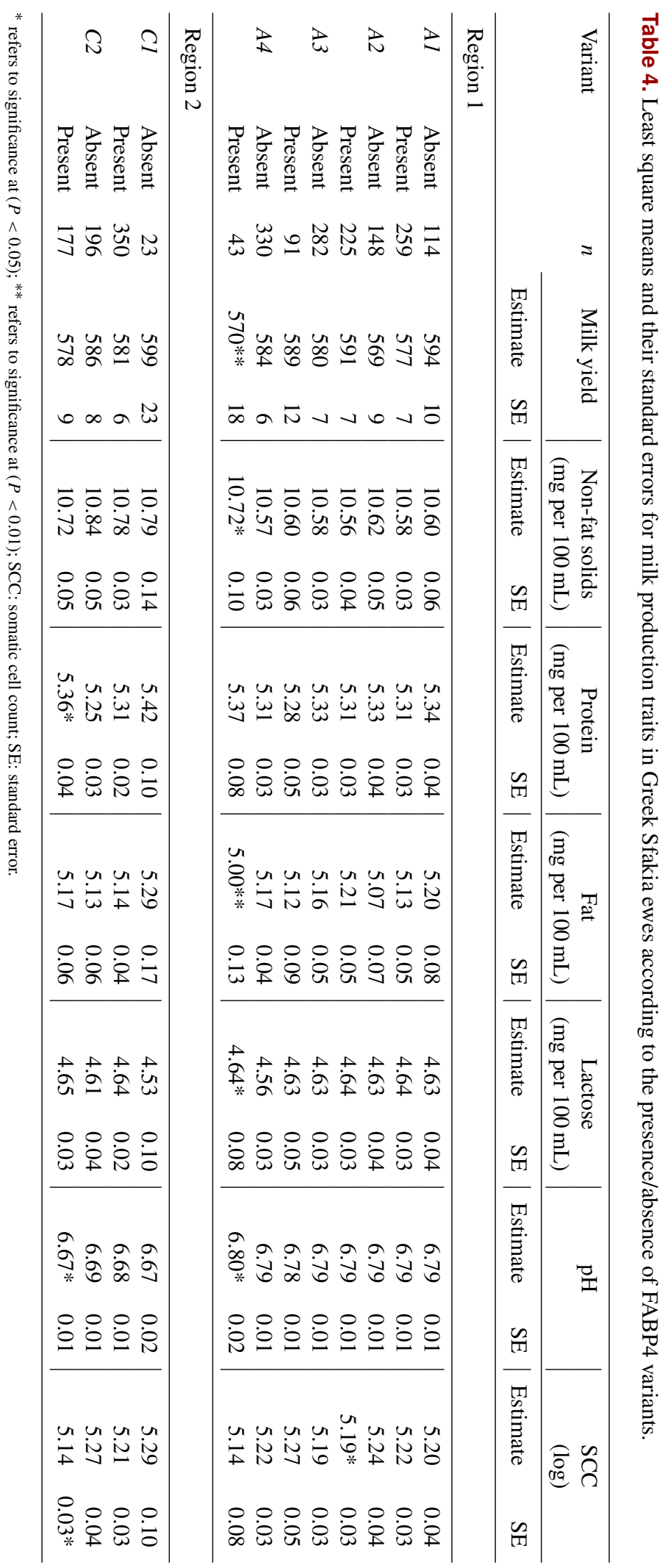



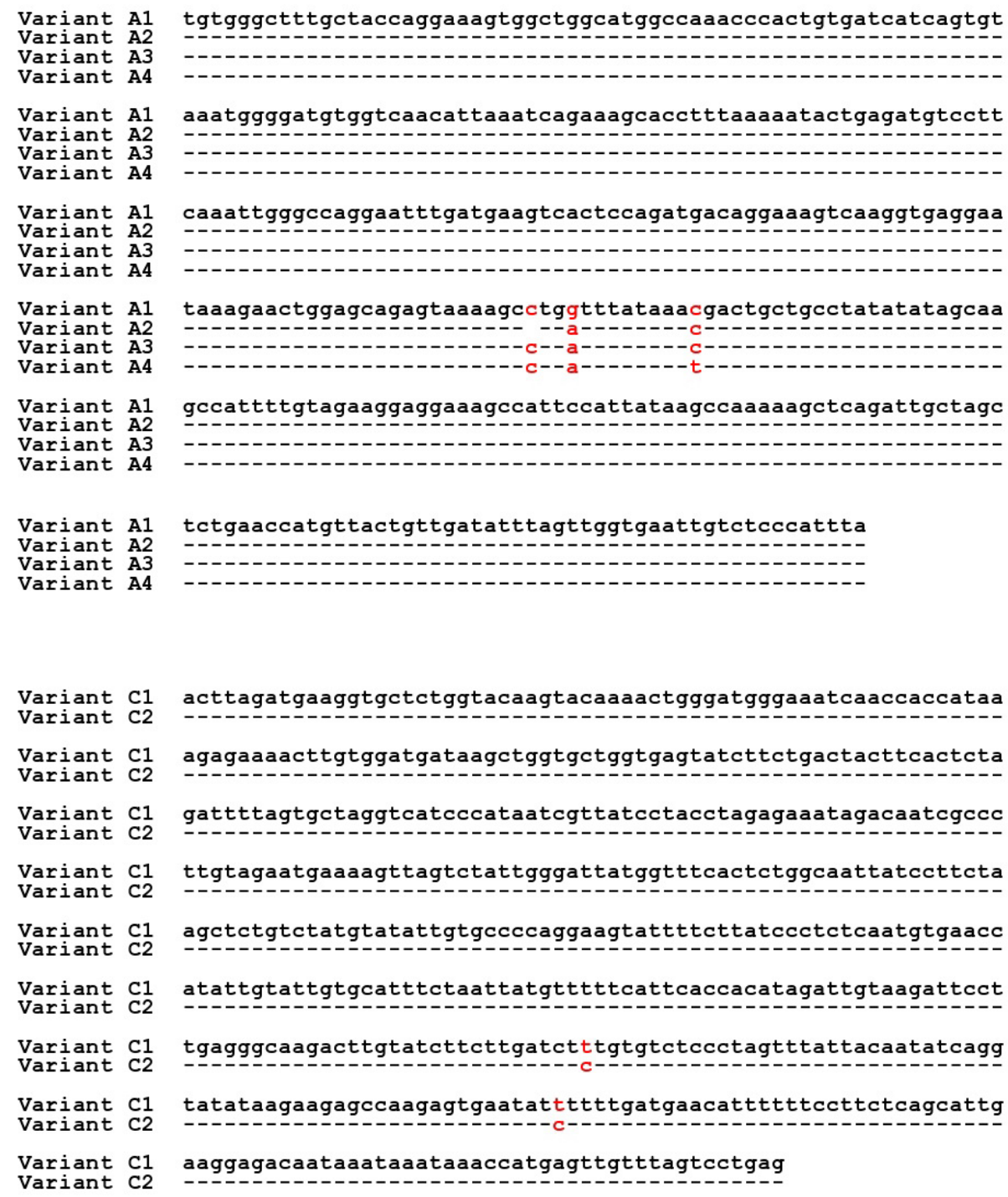

Figure 2. Sequences of the detected variants in Region 1 ( $A 1, A 2, A 3$, and $A 4)$ and Region $2(C 1$ and $C 2)$ of the FABP4 gene in Sfakia sheep.

the single-nucleotide polymorphism (SNP; c.328G $>$ A) on the estimated breeding values for protein yield $(P<0.05)$ and percentage protein content $(P<0.01)$. The same SNP (c.328G > A) was tested in Polish Holstein-Friesian blackwhite cows by Kaczor et al. (2017), but they did not find any effects for this SNP on milk performance traits. Nafikov et al. (2013) sequenced the exonic and some intronic regions of FABP4 to discover the SNPs and haplotypes associated with milk fat percentage and fatty acid composition and reported that the overall haplotype effect of $F A B P 4$ was significantly associated with the concentrations of saturated fatty acids (SFA), un-saturated fatty acids (UFA), monounsaturated fatty acids (MUFA), polyunsaturated fatty acids (PUFA), and the SFA/UFA ratio. Zhou et al. (2015) identified three PCR-SSCP patterns derived from five SNPs: two of these SNPs were detected in exon 3 and the other SNPs were detected in intron 3; these five SNPs defined three haplotype sequences (named $A, B$, and $C$ ) and these were associated with milk yield and protein percentage in Holstein-Friesian $\times$ Jersey-cross dairy cows.

Comparison of the exon 3-intron 3 sequences in this study with the sequences described by Yan et al. (2012) revealed that the FABP4 variants $C 1$ and $C 2$ from the Sfakia sheep have the same sequences as two variants previously described in many New Zealand breeds of sheep (named $A 2$ and D2, GenBank accession numbers JX409931 and JX409934, respectively; Table 2 and Fig. 2). It is notable that the $C 2$ variant, which is associated with increased protein content, decreased SCC and lower $\mathrm{pH}$, and carries the nucleotide substitution c.317A/G that would lead to the putative amino acid substitution of lysine with arginine at residue 106. Arginine is one of the most multifunctional amino acids in animal 
cells. It turns into polyamines, which play a key role in the synthesis of protein in mammary epithelial cells (Kim and $\mathrm{Wu}, 2009$ ). Previous studies revealed the importance of arginine in increasing milk protein content. For example, Moreira et al. (2018) described how dietary supplementation with high levels of arginine increased milk production and milk protein in pigs. Clark et al. (1975) found that arginine uptake by the mammary gland associated with milk yield in rabbits and cows; however, O'Quinn et al. (2002) revealed that the rate of arginine catabolism in the lactating sows was greater than that for the pregnant or non-lactating sows. Furthermore, Tian et al. (2017) stated that arginine deficiencies had negative effects on milk yield and milk protein yield. The investigators attributed the effect of arginine to its crucial role in regulating protein turnover in mammary epithelial cells by activating the mechanistic target of the rapamycin (mTOR) cell signaling pathway (Ma et al., 2018).

The lower SCC for milk produced from ewes which carry the $C 2$ variant might be attributable to the substitution of lysine with arginine in FABP4. Many studies have described a positive effect for arginine on reducing the SCC in milk produced from mammals. For example, Chacher et al. (2013) suggested that promotion of the synthesis and metabolism of endogenous L-Arginine, through supplementation with feed additives that elevate blood plasma arginine levels, enhanced immunity, reduced SCC, and reduced the incidence of mastitis in sows. McCoard et al. (2013) found that administration of L-arginine to Romney ewes improved mammary gland health and decreased SCC in the milk produced. Woloszyn (2007) revealed that the cows with high SCC had a significantly lower concentration of arginine in their blood plasma. Alternatively, studies (Troendle et al., 2016; Hachana et al., 2018) have described a positive correlation between the number of somatic cells in milk and its $\mathrm{pH}$. Given that the ewes that carry the $C 2$ variant also produced milk with lower $\mathrm{pH}$, the effect of $C 2$ on SCC may either be mediated via $\mathrm{pH}$ or arginine levels.

The effects of FABP4 variation on milk production traits might also be explained by other phenomena. Besides its direct effects on milk production traits, $F A B P 4$ has been shown to have an effect on residual feed intake and feed efficiency (Cohen-Zinder et al., 2016), subcutaneous fat depth and fatty acid composition of carcass (Hoashi et al., 2008), intramuscular fat (Lee et al., 2010), marbling score and back-fat thickness (Ardicli et al., 2017), and insulin resistance (Hotamisligil and Bernlohr, 2015). Many investigations have shown associations between milk production traits and these traits. Casper (2008) stated that the lower residual feed intake was, the higher feed efficiency was, leading to increased milk production in dairy cows. Marston et al. (1998) speculated that increased milk production was positively associated with greater marbling in beef cows. A strong relationship was found between the development of back-fat thickness and milk protein content in dairy cows (Schröder and Staufenbiel, 2003). A positive correlation of milk yield and milk fat content, with increased subcutaneous fat depth, in dairy cows was revealed by Nogalski et al. (2012). Elevated levels of insulin in plasma were also found to be associated with decreases in milk production and milk lactose content and increases in milk fat and protein contents in Holstein dairy cows and goats (Mackle et al., 1999; Bequette et al., 2001).

\section{Conclusions}

It could be concluded that the variation in ovine $F A B P 4$ has an effect on milk production traits. However, further investigations have to be undertaken on a larger population of Sfakia sheep, or other breeds of sheep, to confirm these findings before they can be recommended to breeding programs to improve milk production traits in sheep.

Data availability. In 2013 Nikolaos Tzanidakis visited the Genemarker Laboratory, Lincoln University, New Zealand, to carry out extensive research to identify genetic markers associated with milk production traits in Sfakia sheep. Unfortunately, the knee of Nikolaos Tzanidakis was broken in an accident and he was obligated to come back to Greece. Then, Jonathan G. H. Hickford, in collaboration with Nikolaos Tzanidakis, asked me (Adel H. M. Ibrahim, from Egypt) to continue this work. Therefore, I (Adel H. M. Ibrahim) have no right to share the Greek sheep data.

Author contributions. AHMI genotyped all of the ewes and wrote this article. NT and SS collected the data. HZ analyzed the data. JH supervised the research project and corrected the article.

Competing interests. The authors declare that they have no conflict of interest.

Disclaimer. The care and use of experimental animals were performed in accordance with the ethical standards laid down in the 1964 Declaration of Helsinki and its later amendments.

Acknowledgements. The first author thanks the Partnership and Ownership Initiative (ParOwn), the Egyptian ministry of Higher Education, for funding and supporting his mission in New Zealand.

Financial support. This research has been supported by the Partnership and Ownership Initiative (ParOwn), ministry of Higher Education, Egypt (grant no. 2012).

Review statement. This paper was edited by Steffen Maak and reviewed by Galal Abou Khadiga and one anonymous referee. 


\section{References}

Ardicli, S., Samli, H., Alpay, F., Dincel, D., Soyudal, B., and Balci, F.: Association of single nucleotide polymorphisms in the FABP4 gene with carcass characteristics and meat quality in Holstein bulls, Ann. Anim. Sci., 17, 117-130, 2017.

Bequette, B. J., Kyle, C. E., Crompton, L. A., Buchan, V., and Hanigan, M. D.: Insulin regulates milk production and mammary gland and hind-leg amino acid fluxes and blood flow in lactating goats. J. Dairy Sci., 84, 241-255, 2001.

Bionaz, M. and Loor, J. J.: ACSL1, AGPAT6, FABP3, LPIN1, and SLC27A6 are the most abundant isoforms in bovine mammary tissue and their expression is affected by stage of lactation, J. Nutr., 138, 1019-1024, 2008.

Byun, S. O., Fang, Q., Zhou, H., and Hickford, J. G.: An effective method for silver-staining DNA in large numbers of polyacrylamide gels, Anal. Biochem., 385, 174-175, 2009.

Cao, H., Gerhold, K., Mayers, J. R., Wiest, M. M., Watkins, S. M., and Hotamisligil, G. S.: Identification of a lipokine, a lipid hormone linking adipose tissue to systemic metabolism, Cell, 134, 933-944, 2008.

Casper, D. P.: Factors Affecting Feed Efficiency of Dairy Cows. In the Proceeding of Tri-State Dairy Nutrition Conference, April 2008, 133-144, 2008.

Chacher, B., Liu, H., Wang, D., and Liu, J.: Potential role of Ncarbamoyl glutamate in biosynthesis of arginine and its significance in production of ruminant animals., J. Anim. Sci. Biotechnol., 4, 16-21, 2013.

Clark, J. H., Derrig, R. G., Davis, C. L., and Spires, H. R.: Metabolism of arginine and ornithine in the cow and rabbit mammary tissue, J. Dairy Sci., 58, 1808-1813, 1975.

Cohen-Zinder, M., Asher, A., Lipkin, E., Feingersch, R., Agmon, R., Karasik, D., Brosch, A., and Shabtay, A.: FABP4 is a leading candidate gene associated with residual feed intake in growing Holstein calves, Physiol. Genomics, 48, 367-376, 2016.

Gong, H., Zhou, H., and Hickford, J. G.: Diversity of the glycine/tyrosine-rich keratin-associated protein 6 gene (KAP6) family in sheep, Mol. Biol. Rep., 38, 31-35, 2011.

Hachana, Y., Znaidi, A., and M'Hamadi, N.: Effect of somatic cell count on milk composition and mozzarella cheese quality, Acta Aliment., 47, 88-96, 2018.

Hadjigorgiou, I.: Sheep and goat farming and rural development in Greece. In Proceeding of CANEPAL Conference: Celebrating Pastoral Life. Heritage and Economic Development, Athens, Greece, 13 pp., 2014.

Hoashi, S., Hinenoya, T., Tanaka, A., Ohsaki, H., Sasazaki, S., Taniguchi, M., Oyama, K., Mukai, F. and Mannen, H.: Association between fatty acid compositions and genotypes of FABP4 and LXR-alpha in Japanese Black cattle, BMC Genet., 9, 84, https://doi.org/10.1186/1471-2156-9-84, 2008.

Hotamisligil, G. S. and Bernlohr, D. A.: Metabolic functions of FABPs - mechanisms and therapeutic implications, Nat. Rev. Endocrinol., 11, 592-605, 2015.

Hut, C. R., Ro, J. H., Dobson, D. E., Min, H. Y., and Spiegelman, B. M.: Adipocyte P2 gene: developmental expression and homology of $5^{\prime}$-flanking sequences among fat cell-specific genes, P. Natl. Acad. Sci. USA, 83, 3786-3790, 1986.

Kaczor, U., Famielec, M., Dudziak, P., Kaczor, A., Kucharski, M., and Mandecki, A. Fatty acid binding protein 4 (FABP4) and thy- roglobulin (TG) polymorphisms in relation to milk performance traits in the Holstein-Friesian cattle, Acta Sci. Pol. Zootech., 16, 11-16, 2017.

Khan, I. T., Nadeem, M., Imran, M., Ullah, R., Ajmal, M., and Jaspal, M. H: Antioxidant properties of milk and dairy products: A comprehensive review of the current knowledge, Lipids Health Dis., 18, 41, https://doi.org/10.1186/s12944-019-0969-8, 2019.

Kim, S. W. and Wu, G.: Regulatory role for amino acids in mammary gland growth and milk synthesis, Amino Acids, 37, 89-95, 2009.

Król, E., Martin, S. A., Huhtaniemi, I. T., Douglas, A., and Speakman, J. R.: Negative correlation between milk production and brown adipose tissue gene expression in lactating mice, J. Exp. Biol., 214, 4160-4170, 2011.

Kulig, H., Kowalewska-Łuczak, I., Kmieć, M., and WojdakMaksymiec, K.: ANXA9, SLC27A3, FABP3 and FABP4 single nucleotide polymorphisms in relation to milk production traits in Jersey cows, Czech J. Anim. Sci., 55, 463-467, 2010.

Kulig, H., Kowalewska-Luczak, I., Zukowski, K., and Kruszyński, W.: FABP3, FABP4 and ANXA9 SNP genotypes in relation to breeding values for milk production traits in Polish HolsteinFriesian cows, Genetika, 49, 981-985, 2013.

Lee S. H., van der Werf, J. H., Kim, N. K., Lee, S. H., Gondro, C., Park, E. W., Oh, S. J., Gibson, J. P., and Thompson, J. M.: QTL and gene expression analyses identify genes affecting carcass weight and marbling on BTA14 in Hanwoo (Korean Cattle), Mamm Genome, 22, 589-601, 2011.

Ma, Q., Hu, S., Bannai, M., and Wu, G.: L-Arginine regulates protein turnover in porcine mammary epithelial cells to enhance milk protein synthesis, Amino Acids, 50, 621-628, 2018.

Mackle, T. R., Dwyer, D. A., Ingvartsen, K. L., Chouinard, P. Y., Lynch, J. M., Barbano, D. M., and Bauman, D. E.: Effects of insulin and amino acids on milk protein concentration and yield from dairy cows, J. Dairy Sci., 82, 1512-1524, 1999.

Marston, T., Gleghorn, J. F., and Wankel, L. E.: The impact of selecting for marbling on beef cows herds, Agricultural Experiment Station and Cooperative Extension Service, Kansas State University, April, 1998.

MartõÂnez-Pizarro, A., Dembic, M., PeÂrez, B., Andresen, B. S., and Desviat, L. R.: Intronic $P A H$ gene mutations cause a splicing defect by a novel mechanism involving U1snRNP binding downstream of the 5' splice site, PLoS Genet., 14, e1007360, https://doi.org/10.1371/journal.pgen.1007360, 2018.

McCoard, S., Sales, F., Wards, N., Sciascia, Q., Oliver, M., Koolaard, J., and van der Linden, D.: Parenteral administration of twin-bearing ewes with L-arginine enhances the birth weight and brown fat stores in sheep, SpringerPlus, 2, 684, https://doi.org/10.1186/2193-1801-2-684, 2013.

Moreira, R. H., Lanferdini, E., Fonseca, L. S., Chaves, R. F., Garbossa, C. A., Saraiva, A., Nogueira, E. T., and de Abreu, M. L.: Arginine improves nutritional quality of sow milk and piglet performance, Braz. J. Ani. Sci., 47, e20170283, http://doi.org/10.1590/rbz4720170283, 2018.

Nafikov, R. A., Schoonmaker, J. P., Korn, K. T., Noack, K., Garrick, D. J., Koehler, K. J., Minick-Bormann, J., Reecy, J. M., Spurlock, D. E., and Beitz, D. C.: Association of polymorphisms in solute carrier family 27, isoform A6 (SLC27A6) and fatty acid-binding protein-3 and fatty acid-binding protein-4 (FABP3 and FABP4) 
with fatty acid composition of bovine milk, J. Dairy Sci., 96, 6007-6021, 2013.

Nogalski, Z., Wroński, M., Sobczuk-Szul, M., Mochol, M. and Pogorzelska, P.: The effect of body energy reserve mobilization on the fatty acid profile of milk in high-yielding cows, AsianAustral J. Anim. Sci., 25, 1712-1720, 2012.

O'Quinn, P. R., Knabe, D. A., and Wu, G.: Arginine catabolism in lactating porcine mammary tissue, J. Anim. Sci., 80, 467-474, 2002.

Schröder, U. and Staufenbiel, R.: Relationships between backfat thickness, milk yield and fertility traits with resulting standard curves and their application in dairy herd management, Acta Vet. Scand., 44 (Suppl 1): P21, https://doi.org/10.1186/1751-014744-S1-P21, 2003.

Shu, L., Hoo, R. L., Wu, X., Pan, Y., Lee, I. P., Cheong, L. Y., Bornstein, S. R., Rong, X., Guo, J., and Xu, A.: A-FABP mediates adaptive thermogenesis by promoting intracellular activation of thyroid hormones in brown adipocytes, Nat. Commun., 27, 14147, https://doi.org/10.1038/ncomms14147, 2017.

Spiegelman, B. M. and Green, H.: Control of specific protein biosynthesis during the adipose conversion of 3 T3 cells, J. Biol. Chem., 255, 8811-8818, 1980.

Tian, W., Wu, T., Zhao, R., Xu, J., He, Y., and Wang, H.: Responses of milk production of dairy cows to jugular infusions of a mixture of essential amino acids with or without exclusion leucine or arginine, Anim Nutr., 3, 271-275, 2017.

Troendle, J. A., Tauer, L. W., and Grohn, T. G.: Optimally achieving milk bulk tank somatic cell count thresholds. J. Dairy Sci., 100, 731-738, 2016.
Wessagowit, V., Nalla, V. K., Rogan, P. K., and McGrath, J. A.: Normal and abnormal mechanisms of gene splicing and relevance to inherited skin diseases, J Dermatol Sci., 40, 73-84, 2005.

Williams, J. L.: The use of marker-assisted selection in animal breeding and biotechnology, Revue Sci. Tech., 24, 379-391, 2005.

Woloszyn, M.: Natural Variations of Milk Somatic Cell Count in Dairy Cows. PhD thesis submitted to the Swedish University of Agricultural Sciences, Uppsala, Sweden, 2007.

Yan, W., Zhou, H., Luo, Y., Hu, J., and Hickford, J. G.: Allelic variation in ovine fatty acid-binding protein (FABP4) gene, Mol. Biol. Rep., 39, 10621-10625, 2012.

Yan, W., Zhou, H., Hu, J., Luo, Y., and Hickford, J. G.: Variation in the FABP4 gene affects carcass and growth traits in sheep, Meat Sci., 145, 334-339, 2018.

Zeola, N. M., Sobrinho, A. G., Hatsumura, C. T., Borghi, T. H., Viegas, C. R., Barbosa, J. C.: Production, composition and processing of milk from ewes fed soybean Seeds, R. Bras. Zootec., 44, 146-154, 2015.

Zhou, H., Cheng, L., Azimu, W., Hodge, S., Edwards, G. R., and Hickford, J. G.: Variation in the bovine FABP4 gene affects milk yield and milk protein content in dairy cows, Sci. Rep., 12, 10023, https://doi.org/10.1038/srep10023, 2015.

Zhou, H., Hickford, J. G., and Fang, Q.: A two-step procedure for extracting genomic DNA from dried blood spots on filter paper for polymerase chain reaction amplification, Anal. Biochem., 354, 159-161, 2006.

Zhu, M. and Zhao, S.: Candidate Gene Identification Approach: Progress and Challenges, Int. J. Biol. Sci., 3, 420-427, 2007. 